\title{
LITERATURA
}

\section{Sanjin Kodrić}

Filozofski fakultet Univerziteta u Sarajevu

Odsjek za književnosti naroda Bosne i Hercegovine

71000 Sarajevo,

Bosna i Hercegovina

sanjin.kodric@ff.unsa.ba

\section{ŠTA JE BOŠNJAČKA, A ŠTA BOSANSKOHERCEGOVAČKA KNJIŽEVNOST, A ŠTA, PAK, BOSANSKOHERCEGOVAČKA INTERLITERARNA ZAJEDNICA?

\author{
(Prilog književnoteorijskom i književnohistorijskom razumijevanju)
}

\begin{abstract}
,[...] u svjetlu teorije međuknjiževnoga procesa, odnosno posebne interkulturne povijesti književnosti, slučaj bosanskohercegovačke i bošnjačke književnosti ukazuje se svojom kompleksnom izazovnosti, posebnosti, ne kao stranputica, nego kao ozbiljenje trocivilizacijske interkulturne retorte svjetske književnosti: ono što se u svjetskim integracijskim procesima događa globalno, u Bosni, upravo u bosanskom jeziku događa se i lokalno.“ [Kovač 2001: 150]
\end{abstract}

Pojmovi bošnjačke i bosanskohercegovačke književnosti, a potom i pojam bosanskohercegovačke interliterarne zajednice te njihovi odnosi nisu uvijek dovoljno jasno definirani i razgraničeni, što je slučaj i u samoj Bosni i Hercegovini, a posebno izvan bosanskohercegovačkog okvira.

U Bosni i Hercegovini, naime, nerijetko postoji ili se uspostavlja sasvim nepotrebna i neopravdana svojevrsna konkurencija i napetost između koncepcija 
bošnjačke i bosanskohercegovačke književnosti, kao da jedna koncepcija isključuje drugu, odnosno kao da koncepcija bosanskohercegovačke književnosti poništava koncepciju bošnjačke književnosti i obratno. Razlozi za to najčešće su političko-ideološke naravi i tiču se uglavnom političko-ideoloških preferencija zastupnika ove ili one koncepcije, a ne prije svega književnopovijesnih činjenica, odnosno činjenica zakonitosti povijesnog razvoja književnih praksi u Bosni i Hercegovini. To je bio slučaj i u prošlosti, a posebno prije zvaničnog priznavanja zasebnog postojanja najprije bosanskohercegovačke, a potom i tzv. bosanskomuslimanske, tj. bošnjačke književnosti u današnjem smislu riječi tokom sedamdesetih godina 20. st. [usp. Kodrić 2010, 2012a i sl.], ali se slično dešava i danas, mada iz nešto različitih, drugačijih razloga.

Izvan Bosne i Hercegovine slučaj je još kompleksniji. U izvanbosanskohercegovačkom kontekstu često, naime, vlada stvarna konfuzija, pa se tako, između svega ostalog, u nekim slučajevima pojmovi bošnjačke i bosanskohercegovačke književnosti međusobno izjednačavaju i zamjenjuju, čak se katkad koriste i kao sinonimi, a što je u osnovi pogrešno i književnohistorijski neprihvatljivo. U nekim drugim slučajevima, pak, više ili manje prenebregava se jedna od ovih dviju književnosti, najčešće bošnjačka književnost, čija se koncepcija pritom u pravilu razumijeva kao tobože svojevrstan političko-ideološki konstrukt zasnovan na politikamaiideologijamaaktuelnihetno-nacionalizamaudanašnjempostjugoslavenskom kulturalnom i društvenom kontekstu, što također nema svoje realno književnohistorijsko utemeljenje. U tim slučajevima ponekad se radi i o pukom svjesnom ili nesvjesnom slijeđenju u osnovi vještačkih kontraverzi u vezi s odnosima bošnjačke i bosanskohercegovačke književnosti koje postoje u samoj Bosni i Hercegovini te nekadašnjoj Jugoslaviji, a nekad i o nedostatku stvarnih saznanja o onome što je književna situacija u Bosni i Hercegovini, čija je književnost dugo vremena bila vrlo slabo poznata, pa i sasvim nepoznata izvan bosanskohercegovačkih, a posebno nekadašnjih jugoslavenskih okvira, izuzimajući, naravno, iznimne pojave poput književnog djela Ive Andrića ili Meše Selimovića. Pritom, a da situacija bude još kompleksnija, u ovim i ovakvim slučajevima nerijetko se pod pojmom bosanskohercegovačke književnosti podrazumijeva dominantno bošnjačko književno stvaranje, dok se književni rad nebošnjačkih autora vezuje prvenstveno za okvire hrvatske ili srpske književnosti, a što je slučaj i s nekim bošnjačkim piscima, poput upravo Meše Selimovića, koji je izvan Bosne i Hercegovine uglavnom poznatiji kao srpski, a manje (i) kao bosanskohercegovački i još manje (i) kao bošnjački autor. A tako se i u međunarodnom kontekstu šire složene i često bizarne rasprave o problemima književne pripadnosti pojedinih pisaca, rasprave koje najčešće najmanje veze imaju s pitanjima književne historiografije, već nažalost mnogo više sa starim i novim političko-ideološkim koncepcijama na širem nekadašnjem jugoslavenskom prostoru.

Pri svemu ovom, strada, naravno, prvenstveno sama književnost, a potom i književna historiografija, koju se, pritom, neprestano pokušava uvući u političko-ideološka trvenja s kojima nauka o književnosti u osnovi nema, a posebno ne bi smjela imati ovakav odnos. Naravno, ovakvo proizvedena slika književne 
prošlosti Bosne i Hercegovine nečinjenična je i netačna, odnosno ne odgovara onom što su stvarni, realni književnopovijesni procesi i pojave u Bosni i Hercegovini. Tako se šteta nanosi i književnohistorijskoj interpretaciji i bosanskohercegovačke i bošnjačke književnosti, ali i drugih književnosti u Bosni i Hercegovini. Jer, npr., poistovjećivanje bosanskohercegovačke i bošnjačke književnosti, bez obzira na način i osnovu temeljem koje se takvo što ostvaruje, štetno je i za bosanskohercegovačku i za bošnjačku, a posebno za hrvatsku i srpsku književnost u Bosni i Hercegovini, kao i književne tradicije drugih, manjinskih bosanskohercegovačkih etno-nacionalnih zajednica, poput jevrejske i drugih. Zanemariti, naime, u cjelini bosanskohercegovačkog književnog stvaranja hrvatsku ili srpsku književnost u Bosni i Hercegovini, ili književnu tradiciju bosanskohercegovačkih Jevreja, znači i osiromašiti ono što je realna povijesna složenost i višestrukost književnih praksi u Bosni i Hercegovini, ali istovremeno znači i lišiti npr. hrvatsku ili srpsku književnost iz Bosne i Hercegovine veze sa samom Bosnom i Hercegovinom, odnosno bosanskohercegovačkim književnim i kulturalnim kontekstom, koji je i hrvatskoj i srpskoj književnosti u Bosni i Hercegovini također ključno važan, jednako kao i konteksti hrvatske ili srpske književnosti izvan Bosne i Hercegovine.

Što se tiče bosanskohercegovačke interliterarne zajednice, ovaj pojam tek u posljednje vrijeme ulazi u opticaj, prije svega u bosanskohercegovačkoj književnoj historiografiji, no i tu uglavnom tek sporadično, a izvan Bosne i Hercegovine susreće se vrlo rijetko. Zato, nažalost, pojam bosanskohercegovačke interliterarne zajednice i dalje najčešće funkcionira kao slabo razumljiva apstrakcija, pojam uglavnom nejasan $\mathrm{u}$ širem kontekstu i stoga nedovoljno funkcionalan. $\mathrm{Pa}$ ipak, riječ je, sasvim suprotno, o koncepciji koja - po svemu sudeći - jeste najpodesnija da se objasni složena bosanskohercegovačka književna situacija, odnosno ono što su složene književne pojave u Bosni i Hercegovini i njihovi međusobni odnosi, kao i njihovi odnosi s drugim, srodnim književnostima u širem južnoslavenskom okviru, ili okviru južnoslavenske interliterarne zajednice. Pritom, ideja bosanskohercegovačke interliterarne zajednice nije nipošto tek pomodnost kojom se još dodatno usložnjava slika književnih praksi u Bosni i Hercegovini, već, naprotiv, ideja koja u bosanskohercegovačkoj književnoj situaciji može biti nesumnjivo vrlo produktivna, a uz to je i ideja bliska i nekim dosadašnjim pokušajima razrješenja bosanskohercegovačkog književnog problema.

Kao i sama Bosna i Hercegovina, i književno stvaranje u Bosni i Hercegovini izrazito je složeno [usp. npr. Rizvić 1985], te predstavlja vrlo kompleksan književnohistorijski problem, ali i izazovno pitanje za teoriju historije književnosti.

Sagledano kao cjelina i u svojem povijesnom trajanju, ono, prije svega drugog, nije ostvareno samo u okvirima jednog naroda, odnosno jedne etno-nacionalne zajednice, pogotovo onda ako se ovakvo što promatra sa sviješću o realnosti složenih procesa etno-nacionalnih identifikacija koji se u Bosni i Hercegovini in- 
tenzivno odvijaju počev od sredine 19. st. pa nadalje, sve do danas, a zahvaljujući kojima nekadašnja relativno homogena pojava bosanskog naroda razvila se tokom vremena $u$ najmanje tri zasebne etno-nacionalne zajednice, prvenstveno tragom njihovih ranijih religijsko-konfesionalnih identifikacija i veza ove vrste $u$ širem južnoslavenskom kontekstu. Ovom, karakterističnom novovjekovnom i savremenom bosanskohercegovačkom etno-nacionalnom ,trolistu” potrebno je dodati i činjenicu postojanja i drugih naroda u Bosni i Hercegovini, od koji su neki ostvarili i čitave vlastite književne tradicije, a među kojima, uz druge manjinske zajednice, najpoznatiji primjer jesu bosanskohercegovački Jevreji i njihova vlastita, jevrejska književna tradicija u Bosni i Hercegovini. Tako, u Bosni i Hercegovini u ovom smislu kao realnost i činjenica postoje paralelne književne prakse najmanje tri, odnosno četiri uglavnom jasno zaokružene i prepoznatljive etno-nacionalne zajednice, sve to i uz svijest o širem bosanskohercegovačkom okviru, svijest koja je u pojedinim vremenima i pojedinim slučajevima više ili manje izražena, ili manje ili više rado prihvaćena i afirmirana, odnosno svijest koja je u nekim povijesnim trenucima jačala i dovodila do približavanja, pa i gotovo cjelovitog stapanja ovih pojedinačnih etno-nacionalnih književnih tokova u jedan i jedinstven književni sistem, dok je u nekim drugim vremenima bila slabija ili sasvim slaba, imajući za rezultat manju ili veću udaljenost, pa i punu odvojenost i zasebnost književnog rada i književnog života u Bosni i Hercegovini.

Književno stvaranje u Bosni i Hercegovini, također, nije ostvareno na samo jednom jeziku, kao ni na samo jednom pismu. To se, naravno, ne odnosi prvenstveno na savremenu činjenicu supostojanja triju zvaničnih službenih jezika u Bosni i Hercegovini - bosanskog, hrvatskog i srpskog, a koji lingvistički predstavljaju u osnovi jedan (iako ne dokraja jedinstven) jezički sistem, odnosno ne odnosi se tek na zvanične, a zapravo katkad i tek formalne jezičke etikete. Štaviše, osim na maternjem, književni rad u Bosni i Hercegovini ostvarivan je i na drugim jezicima - na starobosanskom, odnosno staroslavenskom i crkvenoslavenskom, na turskom, perzijskom i arapskom, na latinskom, na hebrejskom, jevrejskošpanskom ili ladinu, uz pojedine primjere i na drugim jezicima. Slično ovom, književnost u Bosni i Hercegovini pisana je i na glagoljici, i na staroj bosanskoj ćirilici - bosančici, i na arebici, kao i na različitim starijim i novijima varijantama latinice i ćirilice te na hebrejskom pismu, dakle na pismima ne samo različitih jezika već i različitih kulturnih, pa i civilizacijskih tradicija.

Isto tako, književnost u Bosni i Hercegovini stoljećima je bila i sastavni dio različitih i širih književnih, ali i kulturno-civilizacijskih sistema. U svojim počecima, kao i srednjovjekovna Bosna, dio je medievalne kulture evropskog tipa, ali na razmeđu njegova zapadnog $i$ istočnog modela, a sve to, po svemu sudeći, u svojoj osobenoj, bosanskoj varijanti kakvu su njegovali srednjovjekovni bosanski starenici - bosanski krstjani, „dobri Bošnjani”. S ulaskom Bosne u granice Osmanskog carstva (1463), književno stvaranje u Bosni i Hercegovini ulazi i u okvire orijentalno-islamske kulture i civilizacije, što je, naravno, najočitije u slučaju književne prakse bosanskih muslimana - Bošnjaka, ali je na različite načine i u različitim oblicima ovakvo što svoje tragove ostavilo i u književnoj baštini drugih bosan- 
skohercegovačkih religijsko-konfesionalnih, odnosno etno-nacionalnih zajednica. Nakon nešto više od četiri stoljeća zvanične osmanske vlasti u Bosni (1463-1878) slijedi i austrougarska okupacija (1878), a potom i aneksija Bosne (1908), s čim u vezi u punom kapacitetu počeo se odvijati dugotrajan i složen proces ,evropeizacije" cjelokupnog bosanskohercegovačkog društva, pa tako i kulture te same književnosti, a zapravo proces svojevrsne ,repatrijacije“ Bosne u okvire evropske kulture i civilizacije [usp. npr. Kodrić 2012b]. Istina, ovi procesi započeti su još u posljednjim desetljećima osmanske vlasti u Bosni kao dio šireg projekta usvajanja nekih od tekovina moderne Evrope u samom Osmanskom carstvu [usp. npr. Kodrić 2015], a i tad, a posebno kasnije, na važne načine odrazili su se u svim pojedinačnim književnim praksama u Bosni i Hercegovini. Međutim, ni ovaj prvi, kao ni drugi val usvajanja evropskih kulturnih i civilizacijskih stečevina neće predstavljati i čin odbacivanja orijentalno-islamskog naslijeđa, naročito kod bosanskomuslimanske, bošnjačke zajednice, već je posrijedi izrazito interkulturalna situacija s čitavim šarenilom prijelaznih, hibridnih i sinkretičkih kulturalnih tvorbi nastalih susretom tradicija muslimanskog Orijenta i aktuelnih oblika kulture evropskog Zapada [usp. npr. Kodrić 2014]. Ovakvo što nastavit će se i dalje razvijati i u kasnijim vremenima, uz pojavu i usvajanje elemenata različitih drugih kulturalnih dominanti, koje će se u cjelini bosanskohercegovačkog društva javljati slijedom uključenja Bosne u različite državne tvorbe i njihove kulturalne projekte od Kraljevine Srba, Hrvata i Slovenaca kao začetka zajedničke jugoslavenske države pa sve do njezina konačnog raspada tokom ratnih devedesetih godina 20. st. i obnove bosanskohercegovačke državne samostalnosti, a što će - sve zajedno - književnost u Bosni i Hercegovini učiniti naročito složenom upravo i u kulturalnom smislu.

Ova i ovakva književnohistorijska i kulturalnohistorijska realnost predstavlja onu osnovu na kojoj je danas moguće govoriti i o jedinstvenoj, singularnoj književnosti Bosne i Hercegovine, odnosno o bosanskohercegovačkoj književnosti, koja se nekad naziva i bosanska književnost, prema povijesnom imenu Bosne i Hercegovine, ali, isto tako, moguće je istovremeno govoriti i o paralelnim, pluralno između sebe postavljenim književnostima Bosne i Hercegovine - bošnjačkoj te hrvatskoj i srpskoj književnosti u Bosni i Hercegovini. Ovim trima bosanskohercegovačkim književnostima nužno je, pritom, dodati i književne tradicije bosanskohercegovačkih manjinskih zajednica poput jevrejske i drugih, koje se nisu uvijek uspjele razviti u kompleksnije književne sisteme, pogotovo ne s dokraja kontinuiranim književnopovijesnim slijedom, ali koje i dalje jesu književnopovijesne činjenice i realnost koja se kao takva treba i mora uvažiti, tim prije što su književne tradicije ove vrste pogotovo u pojedinim razdobljima književne prošlosti pokazivale svoju nesumnjivu unutrašnju zaokruženost i cjelovitost, kako je to npr. bio slučaj upravo s jevrejskom književnom tradicijom u Bosni i Hercegovini čak sve do Drugog svjetskog rata. A na temelju svega ovog u konačnici nužno je govoriti i o pojavi koju je s obzirom na njezinu vlastitu, unutrašnju povijesnorazvojnu dinamiku i uopće njezine povijesnorazvojne zakonitosti i odnose vjerovatno najprimjerenije odrediti pojmom bosanskohercegovačka interliterarna zajednica. 
Riječ je o fenomenu koji je definiran na temeljima danas posebno važnih teorijskih ideja interliterarnosti, a koje su naročito korisne upravo u slučaju kompleksnih književnih situacija kakva je i književna situacija u Bosni i Hercegovini. No, da bi se ove teorijske ideje mogle adekvatno upotrijebiti u nastojanju da se književnohistorijski realno, dakle objektivno i činjenično definira cjelina pojave književnog stvaranja u bosanskohercegovačkom okviru, potrebno je detaljnije predstaviti upravo to kako se ideja interliterarnosti odnosi spram koncepcije pojedinačnih književnosti i njihovih međusobnih odnosa. To pitanje posebno je važno upravo u slučaju bosanskohercegovačke interliterarne zajednice, odnosno onda kad je riječ o odnosima između pojava pojedinačnih književnosti u Bosni i Hercegovini, u prvom redu bošnjačke i bosanskohercegovačke književnosti, ali i hrvatske te srpske književnosti u Bosni i Hercegovini te pojedinačnih književnih tradicija bosanskohercegovačkih manjinskih etno-nacionalnih zajednica, sve to tim prije što se često, naime, upravo sama ideja interliterarnosti indirektno ili direktno koristi i u smislu relativiziranja, pa i stvarnog osporavanja postojanja nekih od pojedinačnih bosanskohercegovačkih književnosti ili, pak, same bosanskohercegovačke književnosti kao takve.

Mada se, posebno u Bosni i Hercegovini, u nekim slučajevima prikazuje kao teorijski novitet, ideja interliterarnosti zapravo je stara već više desetljeća. Kao što je poznato, u književnonaučni diskurs uveo ju je, odnosno ključno definirao slovački komparatist Dionýz Ďurišin, koji je teorijskim i praktičnim pitanjima interliterarnosti i s njom najuže povezane književne komparatistike posvetio čitav niz svojih radova, uključujući i knjige kakve su Izvori i sistematika komparativne književnosti [Ďurišin 1974], Komparativna književna istraživanja: Pokušaj metodološko-teorijskog nacrta [Ďurišin 1976], Teorija književne komparatistike [Ďurišin 1984], Teorija interliterarnog procesa [Ďurišin 1989] i Šta je svjetska književnost [Ďurišin 1992, Đurišin 1997]. Osnovno Ďurišinovo polazište bila je ideja književnosti kao sistema, kojom je na novim pretpostavkama nastojao redefinirati metodologiju komparativnih književnih proučavanja, odnosno komparativnu historiju književnosti prije svega, kao i ideju svjetske književnosti, ali je možda i najvažniji prilog ostvario onda kad je riječ o onom pitanju koje je u pravilu izmicalo iz vidokruga dotadašnje komparatistike, a to je razumijevanju složenih suodnosa između pojedinačnih književnosti koje su na neki način međusobno bliske, ali i dalje zasebne književnosti. Takvo što zasigurno ima veze s činjenicom da je neposredni književno-kulturalni kontekst u kojem je i iz kojeg je Durišin razvijao ideju interliterarnosti bio kontekst nekadašnje čehoslovačke književnosti i kulture, koja se kao specifična, izvorno biliterarna i bikulturalna cjelina počela razvijati tek $\mathrm{s}$ formiranjem Čehoslovačke republike 1918. godine. To je i jedan od razloga da su se pojedine Durišinove ideje i u nekadašnjoj Jugoslaviji javile dosta rano, još od šezdesetih godina 20. st. [usp. npr. Ďurišin 1966], a naročito kasnije, u vrijeme pokušaja razrješenja tadašnjih unutarjugoslavenskih književnih odnosa [usp. npr. 
Ďurišin 1991], a posebno popularne postale su s raspadom Jugoslavije i s nastojanjima redefiniranja književnih odnosa u sad već postjugoslavenskom književnom i kulturalnom kontekstu [usp. npr. Đurišin 1993, Đurišin 1994 i sl.].

U knjizi Šta je svjetska književnost Ďurišin je ostvario svojevrsnu sintezu svih svojih ključnih ideja u području interliterarnosti i književne komparatistike, pri čemu središnji pojam njegove teorije interliterarnosti jeste pojam interliterarne zajednice, koji se posebno odnosi upravo na slučaj odnosa i veza između dviju ili više zasebnih a međusobno u nekom smislu bliskih književnosti. Samu interliterarnu zajednicu Ďrišin definira na temeljima ideje književnosti kao sistema - kao „zbir književnosti među kojima postoje više ili manje uski oblici koegzistencije, veća ili manja mjera razvojne uzajamnosti, među kojima se javlja više ili manje izrazita mjera korelacije“, a čije „komponente, nacionalne ili druge pojedine književnosti, imaju pored toga i vlastita, imanentna razvojna usmjerenja“". Riječ je, dakle, o složenoj cjelini koja, preciznije govoreći, predstavlja više od pukog mehaničkog zbroja pojedinačnih književnosti, ali manje od neke nove, šire književne cjeline koja je srasla u jedinstveni, unutar sebe cjelovito zaokruženi književni sistem, odnosno o pojavi nadrastanja pojedinačnih književnih okvira u pravcu postepene izgradnje nekih novih, no koji, međutim, još uvijek nisu dokraja oblikovani. Interliterarna zajednica, zapravo, svojevrstan je književni međusistem, sistemska pojava više razine u odnosu na sisteme pojedinačnih književnosti, ali ne i neki novi književni nadsistem koji bi poništio prethodne književne sisteme. Ovo određenje pojma interliterarne zajednice, međutim, često se, a posebno u Bosni i Hercegovini, pogrešno, pa i sasvim reduktivno tumači, te se naglasak stavlja samo na pojavu interliterarne zajednice u smislu učinka međuknjiževnih odnosa i veza, a zaboravlja se, pa i potpuno previđa ono što Durišin navodi u nastavku ove svojevrsne elementarne definicije pojma interliterarne zajednice: „Njihov je rezultat originalnost i neusporediva samosvojnost svake pojedine književnosti. Taj neposredni faktor samobitne cjeline ne može biti anuliran faktorom drugačijeg tipa.“

Svoj pojam interliterarne zajednice Dionýz Durišin izvodi prvenstveno deduktivno, iz same prakse međuknjiževnih odnosa i veza, prateći ono što je zbilja suodnošenja i povezivanja između pojedinačnih književnosti u realnom književnopovijesnom svijetu. Zato Durišin prednost daje prije svega upravo interliterarnom procesu, odnosno međuknjiževnim odnosima i vezama kao, po njemu, novom i osnovnom predmetu savremene komparatistike, ne favorizirajući, dakle, ni pojedinačne književnosti, ali ni interliterarnu zajednicu kao rezultat interliterarnih procesa. Ďurišin, pritom, nipošto ne odbacuje koncepcije pojedinačnih književnosti ili - kako on to kaže - nacionalnih književnosti, već, štaviše, eksplicitno upozorava upravo na suprotno, pa ističe: „Nacionalnoknjiževno u izvjesnom smislu pretpostavka je interliterarnog.“ Isto značenje ima i sljedeća Ďurišinova eksplicitna napomena: ,Interliterarni proces bilo kakve vrste ne nastaje samo na bazi djela određene aktuelne vrijednosti, već uopćavanjem procesa nacionalne književnosti kao cjeline u određenom historijskom trenutku." Zato, prema Durišinu, „nacionalnoknjiževno predstavlja sistemsko jedinstvo sastavnih dijelova koje je izraženo odnosima i vezama“, a „nosilac interliterarnosti bit će u suštini taj isti 
kompleks odnosa, koji je, međutim, izražen drugačijom sistemskom svrstanošću [...], takvim sistemom odnosa koji će bez razlike da sjedini sve nacionalnoknjiževne pojave“.

Na ovoj osnovi Dionýz Ďurišin govori i o onome što je, barem na prvi pogled, neočekivana sličnost između historije pojedinačne književnosti, ili historije nacionalne književnosti, na jednoj strani, i interliterarne historije književnosti ili historije svjetske književnosti, na drugoj strani:

Jedinstvo interliterarnog i nacionalnoknjiževnog historizma izraženo je zajedničkim interesom za objekt interliterarnih odnosa. Oni su, međutim, neizbježno interpretirani s dvije različite tačke gledanja. Znači, de facto ti isti interliterarni odnosi predstavljaju objekt interesa na dvojaki način: na drugačiji način grade nacionalnoknjiževnu osobenost, a drugačiji interliterarnu ponovljivost $\mathrm{i}$ univerzalnost.

Prema tome, po Ďurišinu, zadatak historije pojedinačne (nacionalne i sl.) književnosti jeste bavljenje pojedinačnim (nacionalnim i sl.) književnim procesima i pojavama, ali sa sviješću i o širim međuknjiževnim vezama i odnosima, dok zadatak interliterarne, odnosno komparativne ili historije svjetske književnosti jeste bavljenje širim, natpojedinačnim ili svjetskim književnim procesima i pojavama, ali sa sviješću i o realnim književnim procesima i pojavama u pojedinačnim književnostima, pri čemu se $i$ jedna $i$ druga na svoje načine bave interliterarnim procesima i pojavama, pristupajući im iz različitih pozicija is različitim smislom, ali uvijek s međusobnom uvjetovanošću. Štaviše, Durišin sasvim ispravo zaključuje da ,proučavanje nacionalnih književnosti sa stanovišta kriterija višeg reda ujedno nudi mogućnost da se dublje i svestranije shvate one pojave nacionalnih književnosti koje su obilježene specifičnim osobinama, ili one koje nam se čine neobilježenim prilikom uključenja u proces nacionalne književnosti““.

Dionýz Ďurišin, izgleda, bio je sasvim svjestan mogućih pogrešnih ili redukcionističkih interpretacija svojih teorijskih ideja i s pozicija historija pojedinačnih književnosti, ali i sa sasvim suprotnih pozicija vezanih za komparativnu ili historiju svjetske književnosti, pa se također sasvim eksplicitno pozabavio i ovim problemom:

Ako nacionalnoknjiževno istraživanje nije u stanju da u interesu uopćavanja na vlastitoj saznajnoj ravni dovede u međusobnu vezu odnose polazne književnosti i drugih književnosti, onda upućuje na gnoseološki izolacionizam i njegovi zaključci imaju samo parcijalni karakter.

Također, nije moguće znati zakonitosti interliterarnog procesa bez istraživanja njegovih materijaliziranih nosilaca - nacionalnih književnosti i pojava koje su njegov sastavni dio (autori, djela i sl.). Ova dvopolnost neizbježan je uvjet saznajnog procesa kod obje spominjane, uzajamno zavisne, ravni. Zato je npr. nelogičan zahtjev da interliterarno istraživanje mehanički ili na neki drugi način zamjenjuje obaveze nacionalnoknjiževnog istraživanja i obratno. Ne može to činiti ako želi sačuvati svoj vlastiti identitet. Zbog toga su eventualni zahtjevi ovakvog karaktera, koji prate interes jednog ili drugog istraživačkog aspekta, diktirani samo jednostranim utilitarizmom koji je usmjeren protiv dijalektički neizbježne komplementarnosti spomenute dvije ravni: ili protiv njegovog interliterarnog ili protiv nacionalnoknjiževnog oblika. Pošto se radi [...] o fenomenima koji se suštinski uvjetuju, ovakav prakticistički utilitarizam na kraju krajeva usmjeren je i protiv one ravni čije interese naizgled primjenjuje. Kada je riječ o nacionalnolnjiževnom aspektu, rezultat je gnoseološki 
izolacionizam i inferiornost, a kada je u pitanju interliterarni aspekt, onda se ispostavlja beživotna apstrahirana nacionalna superiornost.

Za Ďurišina, stvari su, dakle, sasvim jasne: književnohistorijska proučavanja mogu se temeljiti jedino na realnim književnopovijesnim procesima i pojavama, a to će reći i na realnosti postojanja ili nepostojanja međuknjiževnih odnosa i veza određenog tipa u pojedinim povijesnim trenucima, bez redukcija bilo na strani historije pojedinačne, nacionalne ili neke druge književnosti, bilo na strani širih, komparativnih književnohistorijskih proučavanja ili proučavanja usmjerenih ka nekom širem književnom fenomenu, sve do pojave svjetske književnosti.

Pojam bosanskohercegovačke interliterarne zajednice izveden je iz teorije interliterarnog procesa Dionýza Ďurišina, i odgovora onom što Durišin naziva nestandardnim ili posebnim interliterarnim zajednicama, a koje pokazuju posebne oblike književnog suživota, neposredne koegzistencije i izrazite interakcije i sl., odnosno predstavljaju ,čitavu skalu složenih tipova na putu od 'pojedinačne' književnosti (nacionalna književnost i analogne historijske jedinice) do svjetske književnosti“. Isto se odnosi i na ovom blizak jedan drugi pojam neizbježan i u proučavanju književnog stvaranja u Bosni i Hercegovini, a posebno na širem Slavenskom jugu, a to je pojam južnoslavenske interliterarne zajednice, koji je u postjugoslavenskom književnoakademskom kontekstu najcjelovitije definirao zagrebački južnoslavist Zvonko Kovač, prema kojem južnoslavensku interliterarnu zajednicu naročito karakterizira jezička srodnost, djelomična jednojezičnost, prostorna povezanost, povremeni zajednički društveno-politički okviri, različita pripadnost nadnacionalnim prostorima te višestrukost konfesionalno-civilizacijskih krugova [usp. Kovač 2011, Kovač 2005, Kovač 2016 i sl.]. A kako je ideja bosanskohercegovačke interliterarne zajednice, jednako kao i ideja južnoslavenske interliterarne zajednice, zasnovana na teorijskim koncepcijama Dionýza Ďurišina, onda bi se u razumijevanju i bosanskohercegovačkog književnog fenomena u kontekstu teorije interliterarnosti trebalo vratiti upravo Durišinu (kako to, uostalom, čini i Zvonko Kovač), a ne nekim neadekvatnim interpretacijama Durišinove teorije.

Šta je, onda, bosanskohercegovačka interliterarna zajednica i kakvo je stoga mjesto pojedinačnih književnosti u ovom interliterarnom bosanskohercegovačkom okviru? Posebno, kakvo je mjesto bošnjačke književnosti i kakav je pritom njezin odnos s bosanskohercegovačkom književnošću te šta je sa slučajem hrvatske i srpske književnosti u Bosni i Hercegovini, kao i književnim tradicijama bosanskohercegovačkih etno-nacionalnih manjinskih zajednica? Isključuje li, dakle, ideja bosanskohercegovačke interliterarne zajednice ideje pojedinačnih književnosti i književnih tradicija u Bosni i Hercegovini, i je li, slijedimo li Durišina, moguće istovremeno govoriti, npr., i o bošnjačkoj i o bosanskohercegovačkoj književnosti, odnosno isključuju li ove dvije koncepcije jedna drugu? 
Tragom teorijskih postavki Dionýza Ďurišina te određenja južnoslavenske interliterarne zajednice koje je dao Zvonko Kovač, bosanskohercegovačka interliterarna zajednica mogla bi se definirati kao: zbir u pravilu nacionalnih književnosti i književnih tradicija nacionalnih manjina u Bosni i Hercegovini među kojima postoje u prošlosti minimalni ili mali, a kasnije sve veći i izrazitiji oblici koegzistencije, razvojne uzajamnosti i korelacije, čak nadnacionalnog stapanja u jedinstvenu književnu pojavu, a koje imaju pored toga $i$ vlastita, imanentna razvojna usmjerenja, s originalnošću i samosvojnošću svake pojedine književnosti kao značajkama koje ne mogu biti anulirane faktorom drugačijeg tipa; slično južnoslavenskojinterliterarnojzajednici, karakterizirajejezičkavišestrukostuprošlosti, ali i u osnovi lingvistička jednojezičnost u novijem vremenu, neposredna prostorna povezanost, manje-više stabilnizajednički društveno-politički okvirizajednički književnokomunikacijski prostor, ali i različita pripadnost nadnacionalnim prostorima te višestrukost konfesionalno-civilizacijskih krugova, kao i uopće kulturalna složenost $i$ obilje liminalno-hibridnih $i$ sinkretičkih oblika.

Ovako shvaćenu bosanskohercegovačku interliterarnu zajednicu čine bošnjačka te hrvatska i srpska književnost u Bosni i Hercegovini, kao i jevrejska književna tradicija te književne tradicije drugih bosanskohercegovačkih nacionalnih manjina, ali i pojava bosanske ili bosanskohercegovačke književnosti kao nadnacionalnog književnog fenomena. Pojam bošnjačke književnosti odnosi se, naravno, na književno stvaranje Bošnjaka („Bosanskih Muslimana“ ili „Muslimana“, prema ranijoj nominaciji), pri čemu bošnjačka književnost svoje središte ili maticu ima upravo u Bosni i Hercegovini, i u tom smislu dio je bosanskohercegovačke književnosti kao cjeline, s jedne strane, sok, s druge strane, nije ograničena samo na bosanskohercegovački okvir, već također obuhvata bošnjačko književno stvaranje i iz drugih sredina, izvan današnje Bosne i Hercegovine, a posebno iz onih koje su povijesni dio bosanskog konteksta ili gdje su Bošnjaci autohtoni narod (kao npr. u Sandžaku), ili, pak, iz sredina gdje su Bošnjaci odavno etablirana dijaspora s dugom tradicijom (kao npr. u Hrvatskoj ili Makedoniji). Hrvatska i srpska književnost u Bosni i Hercegovini (koje bi se alternativno mogle nazivati i bosanskohrvatskom, odnosno bosanskosrpskom književnošću) književne su prakse bosanskohercegovačkih (ili bosanskih) Hrvata i Srba, pri čemu su one u osnovi dvopripadne, te su istovremeno dio i bosanskohercegovačkog, ali i hrvatskog, odnosno srpskog književnog konteksta, tj. dio i bosanskohercegovačke, ali i hrvatske ili srpske književnosti kao cjeline. Slično je i s manjinskim knjiženim tradicijama, koje također participiraju u cjelini bosanskohercegovačke književnosti, ali su isto tako povezane i s pripadnim nacionalnim književnim maticama izvan Bosne i Hercegovine, kao i s istovrsnim paralelnim manjinskim književnim tradicijama u širem južnoslavenskom okviru.

Pojam bosanskohercegovačke književnosti, pak, u općem smislu riječi odnosi se na ukupnost knjiženog stvaranja u Bosni i Hercegovini, i u tom slučaju uveliko se može izjednačiti s pojmom bosanskohercegovačke interliterarne zajednice, s tim što pojam bosanskohercegovačke književnosti insistira na integralnosti bosanskohercegovačkog književnog stvaranja, za razliku od poj- 
ma bosanskohercegovačke interliterarne zajednice koji prije naglašava osobitu kompozitnost bosanskohercegovačke književne prakse. Međutim, ni sam pojam bosanskohercegovačke interliterarne zajednice također ne negira niti relativizira integralnost bosanskohercegovačkog književnog stvaranja, već tek ukazuje na unutrašnju složenost bosanskohercegovačkog književnog fenomena, što je implicitno prisutno i u koncepciji bosanskohercegovačke književnosti, dok je ovdje takvo što i eksplicitno. Ovako shvaćena bosanskohercegovačka književnost uključuje, naravno, prije svega cjelinu književnog stvaranja u današnjoj Bosni i Hercegovini, s tim što u nekim slučajevima može uključiti i pojave koje izvorno dolaze izvan današnjeg bosanskohercegovačkog okvira, a naročito dijasporne književne pojave ili književne pojave iz Sandžaka, ali i druge specifične pojave vezane u većoj ili manjoj mjeri (i) za bosanskohercegovački književni kontekst (između niza drugih, takav je npr. i slučaj književnog djela Silvija Strahimira Kranjčevića, koji je važan dio života proveo upravo u Bosni, gdje je ostavio vrlo dubok i značajan književni trag, zbog čega se jednim dijelom može smatrati piscem povezanim i s bosanskohercegovačkom književnošću, ne sporeći, naravno, njegovu primarnu pripadnost hrvatskoj književnosti).

U vremenu srednjeg vijeka, sve do osmanskog osvajanja Bosne jedino se može govoriti o jedinstvenoj srednjovjekovnoj bosanskoj književnosti, bez bilo kakvih unutrašnjih književnih parcelizacija po konfesionalnoj ili etničkoj, odnosno nekoj drugoj osnovi [usp. npr. Kuna 2008], i to je onaj temelj na kojem će se kasnije razvijati kako pojedinačne bosanskohercegovačke književne prakse, tako i bosanskohercegovačka književnost kao cjelina, odnosno bosanskohercegovačka interliterarna zajednica. S osmanskim osvajanjem Bosne i nestankom srednjovjekovne bosanske države, u drugoj polovini 15 st. započinje specifični razvoj bošnjačke te hrvatske i srpske književnosti u Bosni i Hercegovini u današnjem smislu riječi, a potom, od 16. st., s pridolaskom Jevreja, a onda i drugih manjinskih zajednica, i razvoj njihovih književnih tradicija. Izuzev usmene književnosti, koja nešto drugačije funkcionira, ali i dalje podrazumijeva podjelu na muslimansku i kršćansku folklorno-usmenu tradiciju, pojedinačne bosanskohercegovačke književne prakse, ili pojedinačne književnosti u Bosni i Hercegovini, tokom osmanskog perioda razvijaju se uglavnom bez većih međusobnih dodira i veza, pri čemu su u pravilu dominantno pisane i na različitim jezicima $\mathrm{i} / \mathrm{ili}$ pismima, pa i u kontekstu različitih kulturalno-civilizacijskih sistema. Tako, npr., Bošnjaci bosanski muslimani svoj elitni književni rad ostvaruju na tzv. orijentalno-islamskim jezicima, odnosno na (osmansko)turskom, perzijskom i arapskom jeziku, dok manje-više pučku književnost pod imenom alhamijado književnosti pišu na bosanskom jeziku, ali arebicom, tj. arapskim pismom prilagođenim glasovnom sistemu bosanskog jezika, s tim što su u pojedinim oblicima pisane komunikacije zadržali i staru bosansku ćirilicu - bosančicu, kojom su pisana tzv. krajišnička pisma kao poseban vid epistolarne literature. Pritom, ovakvo bošnjačko pisano-književno stvaranje sastavni je dio onovremenog transkontinentalnog osmanskog, odnosno orijentalno-islamskog konteksta, s malo ili nimalo veze sa stvara- 
njem bosanskih katolika i pravoslavaca, koji prije svega inkliniraju kontekstu zapadnog ili istočnog kršćanstva, usljed čega nastaje i osobiti paradoks da je u ovom vremenu npr. jedan bosanski franjevac ili jedan bosanski pravoslavni monah svojim književnim stvaranjem bliži u književno-kulturalnom smislu autoru iz npr. katoličke Italije ili pravoslavne Rusije negoli autoru muslimanu koji piše u isto vrijeme i u istoj sredini, ali za drugačiju publiku i u drugačijem kulturalno-civilizacijskom poretku.

Tokom osmanskog perioda, dakle, polazna jedinstvena književna osnova iz bosanskog srednjovjekovlja raslojit će se na tri zasebna književna toka bosanskih muslimana, katolika i pravoslavaca, odnosno na zasebne književnosti današnjih Bošnjaka, Hrvata i Srba, uz pojavu i također zasebnih književnih praksi manjinskih zajednica u Bosni, najprije jevrejske, koja je od 16. st. u Bosni ostvarivana na hebrejskom i jevrejskošpanskom jeziku, odnosno ladinu, a tek kasnije, u 20. st. i na jeziku neposredne, bosanske sredine u kojoj stvaraju ovi autori. Ovakva situacija počet će se bitnije mijenjati tek u drugoj polovini 19. st., kad se i u osmanskoj Bosni javljaju prve značajnije proevropske pojave, koje su ovdje rezultat i evropeizacijskih tendencija u samom onovremenom Osmanskom carstvu, ali također pristižu i s druge strane granice, prije svega pod utjecajem književno-kulturnih procesa koji se odvijaju u slavenskim zemljama pod austrougarskom vlašću, naročito u vezi s idejama Ilirskog pokreta. No, stvarne promjene ove vrste nastupit će tek nakon austrougarske okupacije Bosne 1878. godine, kad se Bosna i zvanično uključuje (ili „repatrira” nakon nešto više od četiri stoljeća osmanske vlasti) u zapadno-evropski svijet i njegov književni, odnosno sveukupni kulturalno-civilizacijski kontekst [usp. npr. Rizvić 1985, Kodrić 2012b]. Tad, npr., kod Bošnjaka ubrzano prestaje književno stvaranje na orijentalno-islamskim jezicima, jednako kao i alhamijado književni rad, koji, onda kad se uprkos novom vremenu i zadržavaju u nekom obliku, postoje samo kao subkulturalni književni fenomen, a razvija se književno stvaranje na maternjem, bosanskom jeziku i tzv. zapadnoj pismenosti, što u slučaju bošnjačke kulture označava, naime, pismenost na savremenoj latinici i ćirilici. Slični procesi napuštanja dotadašnje književne tradicije dešavaju se i kod bosanskohercegovačkih katolika i pravoslavaca, odnosno od ovog vremena Hrvata i Srba, čiji se književni rad također uključuje u kontekst moderne Evrope s kraja 19. st., a slično je i kod Jevreja, koji se sad potpunije integriraju u novi književno-kulturalni kontekst. Pri svemu ovom, dešava se i svojevrsno konvergiranje pojedinačnih bosanskohercegovačkih književnih praksi, njihovo međusobno približavanje, ali i uspostavljanje vremenom sve bližih veza s književnim stvaranjem u drugim južnoslavenskih sredinama. Tako se već krajem 19. i početkom 20. st. počinje izgrađivati sve jedinstveniji bosanskohercegovački književni sistem, koji uključuje i javljanje sličnih poetičkih pojava u pojedinačnim bosanskohercegovačkim književnim praksama, kao i za razvoj bosanskohercegovačkog sistema također vrlo važne različite međuknjiževne razmjene i uzajamnosti. Istina, tokom austrougarskog perioda u književnom stvaranju Bosne i Hercegovine književni život $\mathrm{i}$ dalje je jednim značajnim dijelom podijeljen u smislu da se svaka od pojedinačnih bosanskohercegovačkih književnih praksi ili 
književnosti obraća prije svega ili dominantno „svojoj“ čitalačkoj publici, koja je prvenstveno religijsko-konfesionalno, odnosno etno-nacionalno determinirana. Međutim, i s ovim u vezi dolazi do značajnih promjena, pa vremenom dolazi i do sve izraženijeg srastanja sveukupne književne komunikacije i na produkcijskom i na recepcijskom planu, čemu se na različite načine doprinijeli i inače vrlo složeni procesi etno-nacionalnih identifikacija koji se u Bosni i Hercegovini dešavaju $\mathrm{u}$ isto vrijeme. To se naročito odnosi na Bošnjake, odnosno bosanske muslimane, koji se nerijetko priklanjaju hrvatskoj ili srpskoj etno-nacionalnoj identifikaciji, u kontekstu poznatog procesa tzv. nacionaliziranja muslimana [usp. npr. Isaković 1990], što je, uz niz negativnih posljedica, kao pozitivni učinak imao upravo približavanje književnih praksi koje su samo nekoliko desetljeća ranije bilo gotovo u potpunosti međusobno odvojene.

Očito, već s austrougarskim periodom u Bosni i Hercegovini, odnosno prvi put nakon srednjeg vijeka, integralna bosanskohercegovačka književnost ponovo je sve realnija književnopovijesna činjenica. Ovaj proces međusobnog približavanja i u jedinstveni(iji) književni sistem srastanja pojedinačnih bosanskohercegovačkih književnih praksi ili književnosti nastavit će se posebno nakon 1918. godine, sa stvaranjem prve zajedničke južnoslavenske države - Kraljevine, Srba, Hrvata i Slovenaca, odnosno kasnije Kraljevine Jugoslavije. Istina, u isto vrijeme, uz ove integrativne procese, javljaju se i suprotni, dezintegrativni procesi, naročito $u$ vezi s daljnjim nacionaliziranjem bosanskih muslimana na hrvatsku ili srpsku etno-nacionalnu stranu, odnosno u vezi s parceliziranjem Bosne po hrvatsko-srpskoj liniji. Takvo što, naime, dovodilo je i do pojava odbacivanja zvaničnog postojanja i bosanskohercegovačke, a posebno bošnjačke književnosti, mada su one upravo u ovom trenutku dokraja bile konstituirane kao specifični književni fenomeni. Otud, i onda kad je zvanično negirano postojanje ovih književnosti kao takvih, pod ovim ili nekim drugim sličnim imenom, ona su postojale upravo kao književnopovijesne činjenice, prije svega po poetičkoj specifičnosti književnih pojava u Bosni i Hercegovini u odnosu na književne pojave u Hrvatskoj i Srbiji te Crnoj Gori kao sredinama s u osnovi istim, zajedničkim jezikom. Zato upravo period nakon 1918. godine, odnosno između dvaju svjetskih ratova, predstavlja izrazito važno razvojno razdoblje u povijesti književnog stvaranja u Bosni i Hercegovini.

Ovakvo što još više je slučaj s razdobljem nakon Drugog svjetskog rata, u socijalističkoj Jugoslaviji. Doduše, ni u ovom periodu u početku zvanično nije priznavano samostalno postojanje ne samo bošnjačke već ni bosanskohercegovačke književnosti, a njihovi pisci uvrštavani su ili u hrvatsku ili u srpsku književnost. Posebno tragom ranijih procesa nacionaliziranja muslimana, to je naročito bio problem onda kad su u pitanju bili bosanskomuslimanski, odnosno bošnjački autori, pri čemu na apsurdnost ovakvih književnih koncepcija upućuje, između niza drugih, i slučaj braće Dizdar - Mak Dizdar bio je npr. dijelom hrvatske, a njegov rođeni brat Hamid, također pisac, dijelom srpske književnosti. No, zahvaljujući širim promjenama u društvu i politici socijalističke Jugoslavije počev od druge polovine šezdesetih godina 20 . st. pa nadalje, i ovakvo što počinje se mijenjati, 
naročito nakon priznavanja „Muslimana“ kao zasebnog naroda u izmjenama Ustava 1971. te novom Ustavu Socijalističke federativne republike Jugoslavije iz 1974. godine, kad se i zvanično priznaje najprije bosanskohercegovačka, a potom i „muslimanska“, odnosno bošnjačka književnost. Pritom, riječ je o vremenu punog integriranja bosanskohercegovačke književnosti kao takve, ali ne na način isključive centralizacije jer koncepcija bosanskohercegovačke književnosti koja je upravo u ovo vrijeme i zvanično profilirana bila je koncepcija tzv. kompozitne integralnosti, a koja je podrazumijevala istovremeno postojanje i nadnacionalne bosanskohercegovačke književnosti, ali i pojedinačnih etno-nacionalnih književnosti u Bosni i Hercegovini - bošnjačke, tj. u to vrijeme „,muslinske“, hrvatske i srpske, kao i književnih tradicija bosanskohercegovačkih manjinskih zajednica [usp. npr. Kodrić 2010, Kodrić 2012a]. U suštini, riječ je, zapravo, o koncepciji bosanskohercegovačke interliterarne zajednice.

Uzevši u obzir i daljnji razvoj književnosti, odnosno književnih odnosa vezanih za bosanskohercegovačku interliterarnu zajednicu, kao njezin sastavni dio danas je potrebno posmatrati i fenomen sandžačkobošnjačke književnosti, kao naročiti podsistem bošnjačke književnosti koji je vezan za prostore Sandžaka, a putem kojeg bošnjačka književnost ulazi u posebnu vrstu odnosa s književno-kulturalnim kontekstima s jedne s strane Srbije, a s druge strane Crne Gore. Istovremeno, moguće je govoriti i o pojavama različitih dijaspornih književnih praksi, poput npr. bošnjačke književnosti u Hrvatskoj i Makedoniji, a koje također predstavljaju posebne podsisteme bošnjačke književnosti kao i sandžačkobošnjačka književnost, s tim što je ovaj put riječ o bošnjačkoj književnoj enklavi unutar hrvatskog, odnosno makedonskog književno-kulturalnog prostora. Svemu ovome treba dodati i različite međuknjiževne veze i odnose, odnosno različite interliterarne fenomene $u$ koje su pojedine književne prakse iz okvira bosanskohercegovačke interliterarne zajednice ulazile tokom povijesti te i dalje ulaze počev od šireg južnoslavenskog i slavenskog okvira, odnosno preko šireg zapadno-evropskog okvira, pa sve do okvira književnosti i kultura orijentalno-islamskog kruga, i dalje, pri čemu se i danas ponovo javljaju pisci s npr. bilingvalnim književnim djelom, odnosno s istovremenim učešćima u književnostima i kulturama različitih jezika, itd., itd. U tom smislu, danas je moguće govoriti i o pojavi izbjegličko-migrantske književnosti, koja je vrlo često upravo (i) bilingvalna, ali i o pojavama koje je zasad moguće imenovati kao neku vrstu „postjugoslavenske književnosti“, što je oznaka kojom bi se mogle opisati one književne prakse koje u vremenu nakon raspada socijalističke Jugoslavije, u sad već imaginarnom jugoslavenskom književnom i kulturnom prostoru, nastoje obnoviti i ideju književnog jugoslavenstva i sl. Također, u najnovije vrijeme u okvirima bosanskohercegovačke interliterarne zajednice, kao rezultat slabljenja neposredne književne komunikacije unutar bosanskohercegovačkog okvira, javlja se i zaseban (pod)sistem koji se već imenuje kao „književnost Republike Srpske“, sve to uz i neke druge osobene književne pojave. 
Bosanskohercegovačka interliterarna zajednica nesumnjivo je izrazito složen književni fenomen, a vjerovatno je i jedan od najsloženijih u Evropi.

I prema onom što je književnopovijesna realnost, kao i prema izvornim teorijskim postavkama Dionýza Ďurišina, sasvim je jasno da ideja bosanskohercegovačke interliterarne zajednice ne isključuje, a posebno ne negira istovremeno postojanje pojedinačnih, etno-nacionalnih književnosti u Bosni i Hercegovini, već, štaviše, i sama bosanskohercegovačka književnopovijesna situacija i Ďurišinova teorija upravo afirmiraju ideju književnih višestrukosti i naporednosti, čak insistiraju na istovremenosti različitih književnih pojava na različitim razinama. Zato je npr. i pojava istovremenog postojanja i bošnjačke i bosanskohercegovačke književnosti, odnosno bosanskohercegovačke interliterarne zajednice, bez ikakvih unutrašnjih kontradikcija, u potpunosti u duhu Ďurišinovih ideja. Uostalom ,inter“ odnosi uvijek jesu odnosi između pojedinačnih pojava, a da je Ďurišin temeljitije poznavao nekadašnji jugoslavenski književni slučaj, a posebno da je imao iole bolji uvid u bosanskohercegovačku književnu situaciju, vjerovatno bi mu primjer bosanskohercegovačke interliterarne zajednice, sa svim svojim unutrašnjim složenostima te jednako složenim odnosima sa širom, južnoslavenskom interliterarnom zajednicom, bio jedan od školskih primjera za njegovo teorijsko određenje fenomena interliterarne zajednice kao takve. Jer, Durišin, naime, upravo revidira tradicionalnu ideju historije književnosti, te umjesto tradicionalne statičke slike književne prošlosti uvodi novu, realniju - dinamičku sliku književne povijesti, prema kojoj uz tradicionalno priznavane književne entitete, ili - kako to Durišin kaže - „historijske jedinice“, postoje upravo i one pojave o kojima je ovdje riječ.

Na koncu, ovakvo što jeste i pitanje koje je i bez Ďurišina davno na vrlo sličan način riješila i bosanskohercegovačka književna historiografija počev od ovih pitanjima posvećenih brojnih radova Midhata Begića i Muhsina Rizvića pa do radova Enesa Durakovića, uključujući i nekadašnje radove Radovana Vučkovića ili Ivana Lovrenovića, i dr. [Kodrić 2010, Kodrić 2012a, Kodrić 2012b, Duraković 2003, Duraković 2012, Džafić 2015, Spahić 2016, Spahić 2017 i sl.]. To ne treba ni najmanje čuditi jer, kako je to početkom sedamdesetih godina 20. st., u vrijeme intenzivnih rasprava o bosanskohercegovačkom književnom slučaju, naglasio upravo Midhat Begić, ,jedino takvo viđenje i tretiranje ovih pojava može se nazvati naučnim“ ,jer ono jedino ima svoju zasnovu na istini o kulturnom razvitku pojedinih naroda u Bosni i Hercegovini“" [Begić 1971: 7], odnosno u onom što su stvarne, realne književnopovijesne i kulturalnopovijesne činjenice. Zato su i Ďurišinove književnoteorijske ideje sasvim u skladu s književnohistorijskim zaključcima npr. Muhsina Rizvića, prema kojem, uz pojedinačne bosanskohercegovačke književne prakse ili pojedinačne književnosti u Bosni i Hercegovini kao konstante, isto tako konstanta je svoje vrste i književnost Bosne i Hercegovine, odnosno bosanskohercegovačka književnost u smislu „,ukupnosti“ i ,skupnosti““ svih književnih stvaranja i tradicija u ovom području: 
Pojavnost bosanskohercegovačke književnosti u njenom historijskom sumiranju konstituira nekoliko evidentnih statičkih kategorija i dinamičkih činilaca. Prvo je vertikalna (dijahronijska) ukupnost i horizontalna (sinhronijska) skupnost svih stvaranja i tradicija. Drugo je ono što prva kategorija nužno podrazumijeva - tolerancija koja pretpostavlja postojanje razlika. Treći činilac je zalaženje kao pojava cirkuliranja, difuzije i osmoze književnih pojava, kako u horizontalnom tako u vertikalnom smislu. [Rizvić 1985: 7]

Pri svemu ovom, bosanskohercegovačka književnost, a potom jednako i pojedinačne književnosti u Bosni i Hercegovini za Rizvića su prije svega činjenice „historijske svijesti“, odnosno upravo činjenice realnosti povijesnog razvoja književnih praksi u Bosni i Hercegovini, koje i na pojedinačnoj, etno-nacionalnoj razini i na zajedničkoj, nadnacionalnoj bosanskohercegovačkoj razini predstavljaju nesumnjivu povijesnu datost. S ovim u vezi Rizvić apostrofira i „četiri faktora koji strukturiraju historijsku svijest o bosanskohercegovačkoj književnosti“, a koji su takvi da istovremeno podrazumijevaju i svijest o pojedinačnim etno-nacionalnim književnostima u Bosni i Hercegovini, bez unutrašnje kontradiktornosti i međusobnog isključivanja ovih faktora.

Postoje u daljem razmatranju četiri faktora koji strukturiraju historijsku svijest o bosanskohercegovačkoj književnosti: a. Svijest (genetička) svake književne tradicije o sebi i sopstvenom kontinuitetu. b. Svijest o bosanskohercegovačkoj skupnosti koja proizlazi iz imanentne i evidentne tolerancije prema drugim književnim tradicijama, te iz znanja o autohtonom položaju svake tradicije na bosanskohercegovačkom tlu. c. Svijest o međusobnim odnosima koji su nužnost na liniji zajedničkog jezika, bolje rečeno kada se historijski posmatra, fundamentalne jezičke baze, zatim, na liniji historijske nužnosti življenja i interesa održanja, na liniji zajedničke uzajamne tematike, ideologije socijalnog opstanka, te, najzad, na liniji interesa stilsko-estetskih dodira i prožimanja. d. Svijest o prirodnom zalaženju u matične literature kod srpskih i hrvatskih pisaca. Kod bosansko-muslimanskih pisaca - uzimanje srpskih i hrvatskih književnih djela kao uzora na liniji književnostilskih osobina srpskohrvatskog jezika te južnoslavenske, kasnije jugoslavenske uzajamnosti. [Rizvić 1985: 7]

Riječ je, dakle, o onom što je višestruk, pluralan i policentričan književnohistorijski model bosanskohercegovačke književnosti, a koji u cjelini povijesnog razvoja, a ne tek u pojedinim vremenskim odsječcima podrazumijeva paralelno postojanje ipojedinačnih etno-nacionalnih književnostiu Bosnii Hercegovinii same bosanskohercegovačke književnosti, odnosno književnosti Bosne i Hercegovine, sve to u skladu i s koncepcijom interliterarnosti Dionýza Ďurišina, odnosno idejom bosanskohercegovačke interliterarne zajednice.

Ovako složena bosanskohercegovačka književna situacija, koja podrazumijeva i postojanje pojedinačnih, etno-nacionalnih književnosti u Bosni i Hercegovini zajedno s književnim tradicijama pojedinih bosanskohercegovačkih nacionalnih manjina, i postojanje bosanskohercegovačke književnosti kao takve, odnosno postojanje bosanskohercegovačke interliterarne zajednice, na ključan način odražava se i na definiranje same bosnistike. Pritom, a s obzirom na to da se pojedine sastavnice bosanskohercegovačke interliterarne zajednice vezuju i za druge južnoslavenske književnosti, prije svega za hrvatsku i srpsku, a potom i za crnogorsku, određenje bosnistike u obzir mora uzeti i ovakvo što. A to onda znači da je bosnistiku potrebno definirati barem dvostruko, u dva smisla. 
U prvom, širem smislu, bosnistika predmetno obuhvata cjelokupno književno stvaranje vezano za okvire bosanskohercegovačke interliterarne zajednice. Ona se u predmetnom smislu tiče cjeline književnog stvaranja u Bosni i Hercegovini, ali i u vezi s Bosnom i Hercegovinom i njezinim književno-kulturalnim kontekstom, pa u tom smislu uključuje ne samo bošnjačku te hrvatsku i srpsku književnost u Bosni i Hercegovini i književnu praksu bosanskohercegovačkih manjinskih zajednica već i npr. sandžačkobošnjačku književnost, a potom i književnost dijaspornih autora, kako iz etabliranih dijaspora poput dijaspore u Hrvatskoj ili Makedoniji, tako i iz drugih dijaspornih sredina itd. U problemskom smislu, a uzevši u obzir upravo interliterarni karakter bosanskohercegovačke interliterarne zajednice, šire shvaćena bosnistika posebno bi se trebala baviti pitanjima međuknjiževnih odnosa i veza unutar ovakvo shvaćenog bosanskohercegovačkog književnog (među)sistema, odnosnom pitanjima odnosa i veza najrazličitijih vrsta između sastavnica bosanskohercegovačke interliterarne zajednice u svoj njezinoj višestrukosti i složenosti. Definirati u ovom smislu i bosanskohercegovačko književno jedinstvo i unutarbosanskohercegovačke pojedinačne specifičnosti bili bi, otud, neki od temeljnih zadataka šire shvaćene bosnistike, sve to uz još šira interliterarno-komparativna povezivanja s pitanjima kroatistike i srbistike te monenegristike, kao i uopće južne slavistike i slavistike te još šire, uključujući i npr. široka evropeistička ili orijentološka pitanja itd.

U drugom, užem smislu, bosnistika je vezana za bošnjačku književnost kao takvu, i u ovom kontekstu ekvivalentna je kroatistici ili srbistici (slučaj montenegristike, pak, bliži je slučaju bosnistike u širem smislu riječi). Po prirodi stvari, ovakvo shvaćena bosnistika jeste predmetno usmjerena prije svega na bošnjačku književnost, ali ni u ovom slučaju proučavanja bošnjačke književnosti ne mogu isključiti veze i odnose bošnjačke književne prakse s književnošću ostatka bosanskohercegovačke interliterarne zajednice, kao ni još šira interliterarna pitanja, a s obzirom na izrazito interliterarni karakter bošnjačke književne povijesti. Tako je bosnistika u užem smislu uvijek nužno vezana za bosnistiku u širem smislu, i obratno.

No, i šire i uže shvaćena bosnistika najuže je skopčana i sa širim kulturološkim pitanjima. Književnost ne samo da je dio kulture, već je ona jedan od ključnih kulturalnih diskursa, a i sama je bitno kulturalno oblikovana. Pritom, složenost bosanskohercegovačke interliterarne zajednice jeste dominantno složenost upravo u kulturalnom smislu, a što onda bosnistička istraživanja nužno vodi i putem kulturalno orijentiranih proučavanja. Drugačije rečeno, zahvaljujući bosanskohercegovačkoj kulturalnoj složenosti koja se ostvaruje i u složenosti književnog stvaranja u Bosni i Hercegovini, bosnistika je gotovo nužno i kulturalna bosnistika. Što prije osvijesti ovaj svoj na neki način imanentni kulturalni aspekt, to bolje za bosnistiku. Takvo što otvara i brojna nova, često vrlo slabo ili nikako istražena problemska pitanja, poput npr. pitanja liminalnih i hibridno-sinkretičkih oblika itd., a u svakom slučaju predstavlja još cjelovitiji povratak činjenicama o književnoj, ali i s njom usko povezanoj kulturalnoj povijesti Bosne. A tada se pitanja o statusu i karakteru bilo pojedinačnih književnosti u Bosni i Hercego- 
vini, bilo o bosanskohercegovačkoj književnosti ili književnosti Bosne i Hercegovine, odnosno o bosanskohercegovačkoj interliterarnoj zajednici, ukazuju još jasnije, a sama bosanskohercegovačka interliterarna zajednica pokazuje se i kao interkulturalna, tj. kao bosanskohercegovačka interliterarna, ali i interkulturalna zajednica. Pogotovo u takvoj koncepciji, dakle koncepciji kulturalne bosnistike, nikakvih dilema nema niti može biti ni i o tome može li se istovremeno govoriti i o bošnjačkoj i o bosanskohercegovačkoj književnosti, kao i o bosanskohercegovačkoj interliterarnoj (i interkulturalnoj) zajednici. Jer, može, i mora - to je i književna i kulturalna zbilja Bosne, i u povijesti i u savremenosti, a svaki drugi odgovor na ovo pitanje bio bi, kako to kaže Midhat Begić, ipak nenaučan.

\section{Bibliografija}

Begić M. (1971), „Pismo Midhata Begića“, [u:] Odjek, br. XXIV, Sarajevo.

Duraković E. (2003), Bošnjačke i bosanske književne neminovnosti, Vrijeme, Zenica.

Duraković E. (2012), Obzori bošnjačke književnosti, Dobra knjiga, Sarajevo.

Džafić Š. (2015), Interkulturni (kon)tekst bosanskohercegovačke interliterarne zajednice, Dobra knjiga, Sarajevo.

Đurišin D. (1997), Šta je svetska književnost?, prev. Miroslav Dudok, Izdavačka knjižarnica Zorana Stojanovića, Sremski Karlovci / Novi Sad.

Đurišin D. (1993), „Ka metodologiji proučavanja slovenskih književnosti danas“, [u:] Književna istorija, god. 25, br. 90, Vuk Karadžić, Beograd.

Đurišin D. (1994), „O interliterarnom centrizmu balkanskih književnosti“, [u:] Zbornik Matice srpske za slavistiku, br. 46/47, Matica srpska, Novi Sad.

Ďurišin D. (1966), „O teoretskim ishodištima poredbene književnosti“, [u:] Umjetnost riječi, god. 10, br. 3-4, Hrvatsko filološko društvo, Zagreb.

Ďurišin D. (1974), Sources and Systematics of Comparative Literature, trans. Peter Tkác, University of Komenského, Bratislava.

Ďurišin D. (1976), Vergleichende Literaturforschung: Versuch eines methodisch-theoretischen Grundrisses, Sammlung Akademie Verlag, Berlin.

Durišin D. (1984), Theory of Literary Comparatistics, trans. Jessie Kocmanová, Slovak Academy of Sciences, Bratislava.

Ďurišin D. (1989), Theory of Interliterary Process, trans. Jessie Kocmanová \& Zdenek Pistek, Slovak Academy of Sciences, Bratislava.

Ďurišin D. (1991), „Daljnje mogućnosti i perspektive istraživanja međuknjiževnog procesa“, [u:] Komparativno proučavanje jugoslavenskih književnosti, sv. 4, ur. Franjo Grčević, Zavod za znanost o književnosti Filozofskog, Zagreb.

Ďurišin D. (1992), Čo je svetová literatúra?, Obzor, Bratislava.

Isaković A., prir. (199), O ,nacionaliziranju“ Muslimana: 101 godina afirmiranja i negiranja nacionalnog identiteta Muslimana, Globus, Zagreb.

Kodrić S. (2010), „Nevolje s kanonom: Slučaj bosanske i/ili bošnjačke književne historije (Na primjeru okolnosti i karaktera ranog kanonizacijskog rada M. Begića“, [u:] Književna prošlost i poetika kulture (Teorija novog historicizma u bosanskohercegovačkoj književnohistorijskoj praksi), Slavistički komitet, Sarajevo.

Kodrić S. (2012a), ,'Bosanskohercegovačke književne teme' Midhata Begića i problem određenja književnosti u BiH“, [u:] Bosanskohercegovački slavistički kongres I, knj. 2, ur. Sanjin Kodrić, Slavistički komitet, Sarajevo.

Kodrić S. (2012b), Književnost sjećanja: Kulturalno pamćenje i reprezentacija prošlosti u novijoj bošnjačkoj književnosti, Slavistički komitet, Sarajevo. 
Kodrić S. (2014), Istok i Zapad - srce i um (Procesi evropeizacije u novijoj bošnjačkoj književnosti i kulturalno-poetički sinkretizmi i liminalno-hibridni oblici kao specifičnost njezina kulturalnog identiteta), [u:] Sarajevski filološki susreti II, Zbornik radova, knj. 2, ur. Sanjin Kodrić, Bosansko filološko društvo, Sarajevo.

Kodrić S. (2015), Preporod prije preporoda? (Pjesma Pozdrav gospodina hodže Mehmed-Emin-Efendije i počeci novije bošnjačke književnosti), [u:] Radovi, knj. XVIII, Filozofski fakultet, Sarajevo.

Kovač Z. (2001), Poredbena i/ili interkulturna povijest književnosti, Biblioteka Književna smotra, Zagreb.

Kovač Z. (2005), Međuknjiževna tumačenja, Hrvatsko filološko društvo, Zagreb.

Kovač Z. (2011), Međuknjiževne rasprave: Poredbena i/ili interkulturna povijest književnosti, Službeni glasnik, Beograd.

Kovač Z. (2016), Nove interkulturne studije: Međuknjiževna čitanja, mentorstva, Filozofski fakultet Sveučilišta u Zagrebu, Zagreb.

Kuna H. (2008), Srednjovjekovna bosanska književnost, Međunarodni forum Bosna, Sarajevo. Rizvić M. (1985), Pregled književnosti naroda Bosne i Hercegovine, Veselin Masleša, Sarajevo.

Spahić V. (2016), Književnost i identitet: Književnost kao prostor izazova u reprezentaciji/konstrukciji bošnjačkog kulturnog identiteta, Bosanska riječ, Tuzla.

Spahić V. (2017), Krugovi i elipse: Studije i ogledi o književnim identitetima, Bosanska riječ, Tuzla.

\author{
Sanjin Kodrić
}

\title{
WHAT IS BOSNIAK, AND WHAT BOSNIAN-HERZEGOVINIAN LITERATURE, AND WHAT IS, AFTER ALL, THE BOSNIAN-HERZEGOVINIAN INTERLITERARY COMMUNITY? (A CONTRIBUTION TO LITERARY-THEORETICAL AND LITERARY-HISTORICAL UNDERSTANDING)
}

\author{
(Summary)
}

Literary creation in Bosnia-Herzegovina is very complex. Viewed as a whole and throughout its historical duration, it has not been realized within the framework of one nation or one ethno-national community, nor within only one language or only one alphabet, nor within the framework of only one cultural-civilizational circle. This fact and this kind of literary-historical and cultural-historical reality gives the basis from which it is now possible to talk about a unique, singular literature of Bosnia-Herzegovina, or Bosnian-Herzegovinian literature, and also about parallel, plural literatures of Bosnia-Herzegovina - Bosniak as well as Croat and Serbian literatures in Bosnia-Herzegovina, together with the literary traditions of Bosnian-Herzegovinian minority communities, such as the Jewish community and others. Also, it is possible to speak about a phenomenon that should given its own, internal historical-developmental dynamics and its literary-developmental principles and relationships in general - probably be named the Bosnian-Herzegovinian interliterary community. That is why, in understanding the phenomenon of literary creativity in Bosnia-Herzegovina, as well in defining Bosnian literary studies, primarily the theoretical concepts of interliterariness as well as closely related concepts of interculturality occur as potential solutions, as - both of them have their essential meaning and full realization in the cases of both literary and culturally complex phenomena like literature in Bosnia-Herzegovina in general.

Key words: Bosniak literature, Croatian and Serbian literature in Bosnia-Herzegovina, Bosnian-Herzegovinian literature, Bosnian-Herzegovinian interliterary and intercultural community, interliterary process. 